\title{
Incidence of post-harvest fungal diseases of ripe papaya in Mymensingh
}

\author{
I. Hamim*, M. Z. Alam, M. A. Ali and M. Ashrafuzzaman \\ Department of Plant Pathology, Bangladesh Agricultural University, Mymensingh-2202, Bangladesh, *E-mail: \\ islam.hamim@gmail.com
}

\begin{abstract}
A survey was conducted during November, 2012 to May, 2013 to assess the status of major post harvest diseases of papaya fruits in the local markets of Mymensingh. Average percentage of diseased fruits at the markets were 29.83 and diseased fruits ranged from $20.40 \%$ to $38.04 \%$ during the study period. Highest percentage of diseased fruits $(38.04 \%)$ was recorded in the month of May, 2013 followed by March, $2013(37.98 \%)$. The minimum percentage of diseased fruits (20.40\%) was recorded in January, 2013 followed by December (22.68\%). Total six post-harvest diseases was recorded, viz. Anthracnose, Fusarium rot, Stem end rot, Rhizopus rot, Aspergillus rot and Penicillium rot. Anthracnose showed highest mean incidence $(14.17 \%)$ followed by Fusarium rot $(7.26 \%)$ where as Pencillium rot showed lowest mean incidence $(0.70 \%)$. In the market, anthracnose showed maximum percentage of mean disease abundance $(46.11 \%)$ followed by Fusarium rot $(24.61 \%)$. The findings of this study revealed that total six post-harvest diseases are associated with ripe papaya in different markets of Mymensingh. Moreover, May is the predominant month of highest incidence and abundance of all diseases.
\end{abstract}

Keywords: Post-harvest diseases, Ripe papaya, Disease incidence, Disease abundance

\section{Introduction}

Papaya (Carica papaya L.) is grown worldwide in the tropics and subtropics. In Bangladesh, it is one of the leading fruits in respect of acreage and per hectare production in Bangladesh. Recently 1.25 lac metric tons of papaya were produced in Bangladesh from an area of about 1.24 thousand hectares of land with an average yield of 7 ton/ha (BBS, 2011). In Bangladesh yield of papaya, in fact, is far below compared to other countries of the world (Chowdhury, 2008). The availability of the fruit is reduced due to high level of post- harvest loss (Mondal et al., 1995). Approximately 39.9\% post-harvest losses of papaya fruits were estimated in Bangladesh (Hasan, 2010). The value stands for post-harvest losses of papaya fruits is taka 132.91 crore (Hasan, 2010). One of the major reasons of post-harvest losses of papaya production is fungal diseases. Ripe papaya suffers from various post-harvest diseases all over the world. In Bangladesh, there is no information available on the post-harvest fungal diseases of ripe papaya which may occur during the growing season, at harvesting, handling, transport and post-harvest storage and also during marketing, or after purchasing by the consumer. The causal pathogens of the diseases invade the fruits and can cause considerable damage thus rendering it unmarketable. The post-harvest fruit rots bring about a big loss in fruit business which provokes price hike (Uddin, 1995). Assessment of prevalence of the diseases and fruit losses is the key factors in determining the economics of disease management and development of safe management strategies. Therefore, the present study was undertaken with the following objectives:

(i) To know the present status of post-harvest diseases of ripe papaya in Mymensingh district

(ii) To see the incidence and abundance of post-harvest diseases of ripe papaya.

\section{Materials and Methods}

Survey on the post- harvest diseases of papaya was done in the different fruit markets of Mymensingh town during the period of November, 2012 to May, 2013. Four fruit markets, namely Natun bazaar, Shadeshi bazaar, Mesua bazaar and Sankipara bazar of Mymensingh were selected for survey. Four shops were taken randomely from each market. Each of the selected areas was surveyed four times in each month. All varieties of ripe papaya available in the market were considered for disease survey. Diseases were identified by observing different symptoms of post-harvest fungal diseases of papaya described by Alvearaze and Nishijima (1987) and Singh et al. (2012). These symptoms were spot, fruit rot, necrosis, water soaked lesion, corky lesion etc. Diseased fruit samples were collected in polyethylene bags for further symptomatological studies and confirmation of the respective diseases. Beside these, 
total number of fruits, number of diseased fruits, types and number of disease symptoms shown on fruit surface were taken into consideration. The data were collected on monthly basis and calculated in terms of percent disease incidence and abundance by the following formula given by Singh et al. (2012).

$\%$ Disease incidence $=\frac{\text { Loss Number of diseased fruits affected by particular disease }}{\text { Total }} \times 100$

Total number of fruits

$\%$ Disease incidence $=\frac{\text { Loss Number of diseased fruits affected by particular disease }}{\text { Total number of diseased fruits }} \times 100$

\section{Result and Discussion}

A total number of 9391 ripe papaya were inspected in the local markets in and around Mymensingh town during November, 2012 to May, 2013 and 2782 diseased papaya were recorded. Average number of diseased fruits was estimated $29.8 \%$, ranging from $20.40 \%$ to $38.04 \%$ during survey period (Table 1 ). The highest percentage of diseased fruits (38.04) was recorded in May, 2013 followed by March, 2013 (37.98) and the minimum (20.40) in January, 2013. Baiyewu and Amusa (2005), Shivakumar et al. (2002); Eckert and Ogawa (1985) reported the role of post-harvest fungal diseases in the deterioration of papaya during storage and market condition.

Table 1. Per cent diseased fruits of selected fruit markets of Mymensingh during November, 2012 to May, 2013

\begin{tabular}{|c|c|c|c|}
\hline Month & No. of fruits surveyed & Number of diseased fruits & \% diseased fruits \\
\hline November, 2012 & 1350 & 361 & 26.74 \\
\hline December, 2012 & 1389 & 315 & 22.68 \\
\hline January, 2013 & 1235 & 252 & 20.40 \\
\hline February, 2013 & 1760 & 496 & 28.18 \\
\hline March, 2013 & 1888 & 717 & 37.98 \\
\hline April, 2013 & 975 & 339 & 34.77 \\
\hline May, 2013 & 794 & 302 & 38.04 \\
\hline Total & 9391 & 2782 & Mean =29.83 \\
\hline
\end{tabular}

During survey different post-harvest fungal diseases were identified by keen observation of disease symptoms. The identified diseases in the markets were Anthracnose, Fusarium rot, Stem end rot, Rhizopus rot, Aspergillus rot and Penicillium rot (Table 2). Meah and Khan (1987) reported occurrence of different post-harvest diseases in Bangladesh. The diseases also have been reported from India by Rangaswami (1984), Lal et al. (1980), Shivakumar et al. (2002) and Singh et al. (2012). Eckert and Ogawa (1985), Alvarez and Nishijima (1987), Baiyewu and Amusa (2005) also reported the incidence of post-harvest diseases on papaya fruits. Symptoms of the six diseases as recorded during study period are similar to those described by Meah and Khan (1987), Meah et al. (1992), Alvarez and Nishijima (1987) and Singh et al. (2012).

Table 2. Per cent incidence of post-harvest diseases of ripe papaya of selected markets of Mymensingh during November, 2012 to May, 2013

\begin{tabular}{|c|c|c|c|c|c|c|c|c|}
\hline \multirow{2}{*}{ Fungal diseases } & \multicolumn{9}{|c|}{ \% Disease incidence } \\
\cline { 2 - 11 } & Nov, & Dec, & Jan, & Feb, & Mar, & Apr, & May, & Mean \\
2012 & 2012 & 2013 & 2013 & 2013 & 2013 & 2013 & 17.56 \\
\hline Anthracnose & 12.15 & 10.15 & 5.91 & 14.03 & 17.31 & 16.10 & 23.56 & 14.17 \\
\hline Fusarium rot & 5.63 & 5.98 & 5.59 & 7.56 & 11.6 & 8.31 & 6.17 & 7.26 \\
\hline Stem rot & 1.33 & 1.58 & 1.13 & 2.10 & 1.38 & 3.38 & 1.14 & 1.72 \\
\hline Rhizopus rot & 3.11 & 3.46 & 2.51 & 1.59 & 3.55 & 2.77 & 3.28 & 2.89 \\
\hline Aspergillus rot & 2.52 & 3.1 & 2.11 & 1.36 & 2.01 & 2.67 & 2.9 & 2.38 \\
\hline Penicillium rot & 0.89 & 1.22 & 0.73 & 0.28 & 0.58 & 0.41 & 0.76 & 0.70 \\
\hline
\end{tabular}


Percent incidences of different post-harvest diseases on ripe papaya were calculated. Anthracnose incidence on the marketed papaya fruits ranged from $5.11 \%$ to $22.13 \%$. The maximum disease incidence was observed in May, 2013 (23.56\%) followed by March, 2013 (17.31\%). Least disease incidence was found in the month of January, $2013(5.11 \%)$ followed by December $2012(10.15 \%)$. The incidence of Fusarium rot on the ripe papaya ranged from $5.59 \%$ to $11.61 \%$. Highest Fusarium rot incidence was observed in the month of March, $2013(11.61 \%)$ and least disease incidence recorded in the month of January, $2013(5.59 \%)$. In case of stem end rot of ripe papaya diseases incidence was recorded in a range from $1.33 \%$ to $3.38 \%$. Highest and lowest incidence of stem end rot has been recorded in April, $2013(3.38 \%)$ and January, 2013 (1.13\%), respectively. Incidence of other post-harvest diseases like Rhizopus rot, Aspergillus rot and Penicillium rot were also recorded. Mean diseases incidence of Rhizopus rot, Aspergillus rot and Penicillium rot were $2.89 \%, 2.38 \%$ and $0.70 \%$, respectively. Rahman et al. (2008) recorded incidence and severity of major postharvest fungal diseases of Papaya in Selangor, Malaysia. They reported among the diseases, the highest incidence ranged from 90 to $98 \%$ and severity of 25 to $38 \%$ was recorded for anthracnose followed by stem-end-rot.

Among the postharvest diseases, Anthracnose showed maximum mean per cent abundance followed by Fusarium rot $(24.61 \%)$, (Table 3). Anthracnose showed its highest per cent disease abundance in the month of May (61.92) where as Penicillium rot showed least percent disease abundance in the month of February (4.84).

Table 3. Per cent abundance of post-harvest fungal diseases on ripe papaya fruits of selected markets of Mymensingh during November, 2012 to May, 2013

\begin{tabular}{|c|c|c|c|c|c|c|c|c|}
\hline \multirow{3}{*}{ Post-harvest diseases } & \multicolumn{9}{|c|}{ \%isease abundance } \\
\cline { 2 - 10 } & $\begin{array}{l}\text { Nov, } \\
2012\end{array}$ & $\begin{array}{l}\text { Dec, } \\
2012\end{array}$ & $\begin{array}{c}\text { Jan, } \\
2013\end{array}$ & $\begin{array}{c}\text { Feb, } \\
2013\end{array}$ & $\begin{array}{c}\text { Mar, } \\
2013\end{array}$ & $\begin{array}{c}\text { Apr, } \\
2013\end{array}$ & $\begin{array}{c}\text { May, } \\
2013\end{array}$ & Mean \\
\hline Anthracnose & 45.43 & 44.76 & 28.96 & 49.80 & 45.61 & 46.31 & 61.92 & 46.11 \\
\hline Fusarium rot & 21.05 & 26.35 & 27.38 & 26.81 & 30.54 & 23.89 & 16.23 & 24.61 \\
\hline Stem end rot & 4.99 & 6.98 & 5.56 & 7.46 & 3.63 & 9.73 & 3.64 & 6.00 \\
\hline Rhizopus rot & 11.63 & 15.23 & 12.30 & 5.65 & 9.34 & 7.96 & 8.61 & 10.10 \\
\hline Aspergillus rot & 9.42 & 13.65 & 10.32 & 4.84 & 5.30 & 7.67 & 7.62 & 8.40 \\
\hline Penicillium rot & 3.32 & 5.40 & 3.57 & 1.01 & 1.53 & 1.18 & 1.99 & 2.57 \\
\hline
\end{tabular}

The incidence and abundance of post-harvest diseases varied considerably from month to month. Several factors could be involved, most specifically the climate. Maximum diseases were seen in hot summer months (March - May) where as less amount of diseases were observed in the cool winter months (November to January). It may be the result of low temperature. Singh et al., 2012 reported that low temperature reduces respiration, sporulation and enzymatic degradation capacity of disease causing microbes. Present findings also confirm the earlier reports of Lukose and Singh (1997) on pomegranate rot, Baiyewu and Amusa (2005) on papaya rot, Singh and Sumbali (2007) on apple rot, who suggested maximum fungal diseases between the temperature of $30-35^{\circ} \mathrm{C}$ and $80 \% \mathrm{RH}$. Moreover, Paull et al. (1997) suggested that percentage of diseased fruits was greater in the fruit after transit due to the surface injury during fruit transport, handling and packaging. Thus, the above discussion indicates that fungal pathogens and climatic factors involved in the deterioration of commercial papaya fruits.

\section{References}

Adisa, K.A. and Fajola, A.O.1983. Cellulolytic enzymes associated with the soft rots of Citrus sinensis caused by Aspergillus aculeatus and Botryodiplodia theobromae. Mycopathologia., 82:23-27.

Alvarez, A.M. and Nishijima, W.T. 1987. Post-harvest diseases of papaya. Plant Diseases.71 (8): 681686. 
Baiyewu, R.A. and Amusa, N.A. 2005. The effect of temperature and relative humidity on pawpaw fruit rot in south-western Nigeria. World Journal of Agricultural Sciences, 1: 80-83.

BBS. 2011. Year Book of Agricultural Statistics of Bangladesh. Bangladesh Bureau of Statistics. Statistics Divn. Ministry of Planning, Govt. of the Republic of Bangladesh.

Chowdhury, M.G.F., Islam, M.N., Islam M.S., Islam, A.F.M.T. and Hossain, M.S. 2008. Study on preparation and shelf-life of mixed juice based on wood apple and papaya. Journal of soil and nature, 2 (3):50-60.

Eckert, J.W. and Ogawa, J.M. 1985. The chemical control of post-harvest diseases: subtropical and tropical fruits. Annual review of phytopathology, 23: 421-454.

Hassan, M .K. 2010. A guide to postharvest handling of fruits and vegetables, Department of Horticulture. Bangladesh Agricultural University Mymensingh 2202.

Lal, B., Rai, R.N. and Arya, A.1980. Colletotrichum rot of papaya. National Academy of Science Leters 1979. 2(5): 174. Allahabad Univ. India. Review of plant pathology. 59(11):516.

Lukose, C. and Singh, R.D. 1997. Climatic factors affecting the severity of pomegranate fruit rot. Journal of mycology and plant pathology, 27: 48-50.

Mondal, M.F., Rahman, M.A. and Pramanik, M.A.J. 1995. Effects of different post harvest treatments on physio-chemical changes and shelf life of mango. Bangladesh horticulture,.23(1\&2):1-5.

Meah, M.B. and Khan, A.A.1987. Survey of diseases of some important fruit and vegetables of Bangladesh. annual progress report (1986-1987) pp.1-28. Department of Plant Pathology, Bangladesh Agricultural University, Mymensingh.

Meah, M.B., Siddique, M.K., Farooque, A.M. and Siddique, M.A. 1992. Chemical control of papaya anthracnose. Progressive. Agriculture. 3 (1\&2): 27-32.

Paull, R.E., Nishijima, W., Marcelino, R. and Cavaletto, C. 1997. Postharvest handling and losses during marketing of papaya (Carica papaya L.). Postharvest biology and technology, 11:165-179.

Rahman, M.A., Mahmud, T.M.M., Kadir, J., Rahman, R.A. and Begum, M.M. 2008. Major post-harvest fungal diseases of papaya cv. 'Sekaki' in Selangor, Malaysia. Journal of Tropical Agricultural Science, 31 (1): 27.

Rangaswami, G. 1984. Diseases of crop plants in India. Second Edition. pp.363-365. Prentice-Hall of India Private Limited, M-97, Cannaieght Circus, New Delhi 110001.

Singh, P., Mishra, A.K. and Tripathi, N.N. 2012. Assessment of mycoflora associated with postharvest losses of papaya fruits. Journal of Agricultural Technology. 8(3) 961-968.

Singh,Y.P. and Sumbali, G. 2007. Management of Penicillium expansum rot of apples by lactic acid bacteria. Annals of Plant Protection Sciences, 15 (2): 399-401.

Sivakumar, D., Hewarathgamagae, N.K., Wijeratnam, R.S.W. and Wijesundera, R.L.C., 2002. Effect of ammonium carbonate and sodium bicarbonate on anthracnose of papaya. Phytoparasitica, 30: 1-7.

Uddin, M. 1995. Market diseases of papaya and their control. MS thesis. Department of Plant Pathology. Bangladesh Agricultural Univetrsity. Mymensingh. 